\title{
The Long-Run Performance of Asian Commercial Bank Mergers and Acquisition
}

\author{
Sue-Fung Wang1, Yi-Cheng Shih'², Pei-Lung Lin ${ }^{3}$ \\ ${ }^{1}$ Graduate Institute of Finance, College of Management, National Chiao Tung University, Hsinchu, Taiwan, China \\ ${ }^{2}$ Department of Finance and Cooperative Management, College of Business, National Taipei University, Taipei, \\ Taiwan, China \\ ${ }^{3}$ Davicom Semiconductor Inc, Hsinchu, Taiwan, China \\ Email: sfwang@mail.nctu.edu.tw, 초hih.ntpu@gmail.com, peppermintbrand@gmail.com
}

Received 9 February 2014; revised 5 March 2014; accepted 30 March 2014

Copyright (C) 2014 by authors and Scientific Research Publishing Inc.

This work is licensed under the Creative Commons Attribution International License (CC BY).

http://creativecommons.org/licenses/by/4.0/

(c) (i) Open Access

\begin{abstract}
In this paper, we investigate the long-run post-merger performance of Asian acquiring bank by using 293 deals in the 1997-2007 periods. We find the Asian acquiring banks experience negative long-term abnormal returns and are not efficiency improving, followed by mergers and acquisition. However, DeYoung, Evanoff and Molyneux [1] find European bank mergers appear to have resulted in both efficiency gains and stockholder value enhancement and North American bank mergers are efficiency improving, although the event-study literature presents a mixed picture regarding stockholder wealth creation. Therefore, our empirical results show that the long-run stock returns and operating performance of Asian commercial bank mergers are different from those of the US and EU markets. In general, the long-run stock performance and operating performance of Asian commercial bank merger and Acquisition are negative and Asian commercial bank merger and Acquisition cannot create synergy in the long run.
\end{abstract}

\section{Keywords}

Asian Bank Mergers and Acquisition, Long-Run Stock Performance, Long-Run Operating Performance

\section{Introduction}

In the last two decades, the merger activities in banking industry had been a major progress. The reasons for the trend of the consolidation in most countries were financial deregulation, globalization of real and financial mar-

${ }^{*}$ Corresponding author. 
kets and improvements in information technology (Group of Ten [2]).

Within the merger activities, bank mergers happened in the fourth wave from 1980 to 1989, which originated from the US. Since the long-standing geographical restrictions of banking were revoked in the US in 1994 (Riegle-Neal Interstate Banking and Branch Efficiency), bank merger activities were popular within the banking industry. Europe caught up this trend due to the globalization and borderless economy. The banking industry followed the industrial development in Europe after Deregulation was exuberant. During the 1990s, the volume and number of merger and acquisitions increased in the EU (Altunbas and Marqués [3]). Under the circumstances, bank merger activities became a global and borderless activity.

DeYoung, Evanoff and Molyneux [1] provided a review on the post-2000 financial institution merger and acquisitions literature covering over 150 studies, and showed that there are a large number of studies devoted to this issue in the US and the EU. But, there are few studies focused on the Asia bank mergers. They find European bank mergers appear to have resulted in both efficiency gains and stockholder value enhancement and North American bank mergers are efficiency improving, although the event-study literature presents a mixed picture regarding stockholder wealth creation. Shih [4] developed a theoretical model to examine the effect of bank mergers on bankruptcy risk in the Asian Financial Crisis. He showed that merging failing banks are more likely to fail than the predecessor banks, but merging relatively healthy banks are likely to success. However, there are few studies investigating the long-run stock returns and operating performance of Asian bank mergers, therefore we would like to explore whether Asian bank mergers can create the synergy or are inefficient investments in the Asia financial market.

Figure 1 shows Global Financial Mergers Amount in the EU, the US and Asia. The total amounts of bank mergers in Asia are 21,376 from 1980 to 2010. The large deals of the US bank merger happened in 1998. And, the EU started the bank merger from 1984, and approached the average after 2000.

While the Asian Financial Crisis happened from 1997 to 1999, this calamity raised fears of a worldwide economic meltdown. It also had significant macro-level effects in several Asian countries, including sharp reductions in the values of currencies, stocks, and other assets. Local bank regulators encouraged or even forced banks to merger as a way to reduce bank failure risk and stress. After survived from the Asian Financial Crisis, Asia was considered to be the area with the highest growth overall. Figure 2 shows that the real domestic product growth rates in the EU, the US, China and Asia countries from 1980 to 2014. The GDP reflects an increase in the value of all the final goods and services produced within a nation in a given year; thus, it is a measure of economic development. It reveals that the real GDP growth rates in Asia were higher than the US and the EU between 1980 and 2010. Also, the trend is expected to continue in the future years, with the majority of the economic growth in the region fuelled by the rapidly expanding economies of China and India, together with significant growth in certain parts of South Asia, Southeast Asia, and especially East Asia.

According to the report of the bank holding company Goldman Sachs in 2003, there has been rapid economic growth in the developing economies of Brazil, Russia, India and China (collective represented by the acronym "BRICs"). The combined economies of the BRICs are expected to eclipse the combine's economies of the currently richest countries in the world by 2050. The report indicates that economic growth in Asia has been accelerating. Furthermore, Goldman Sachs also reports that the top eleven emerging countries (The Next Eleven), which are the most development potentials in 2008, include Bangladesh, Egypt, India, Iran, Moscow, Nigeria,

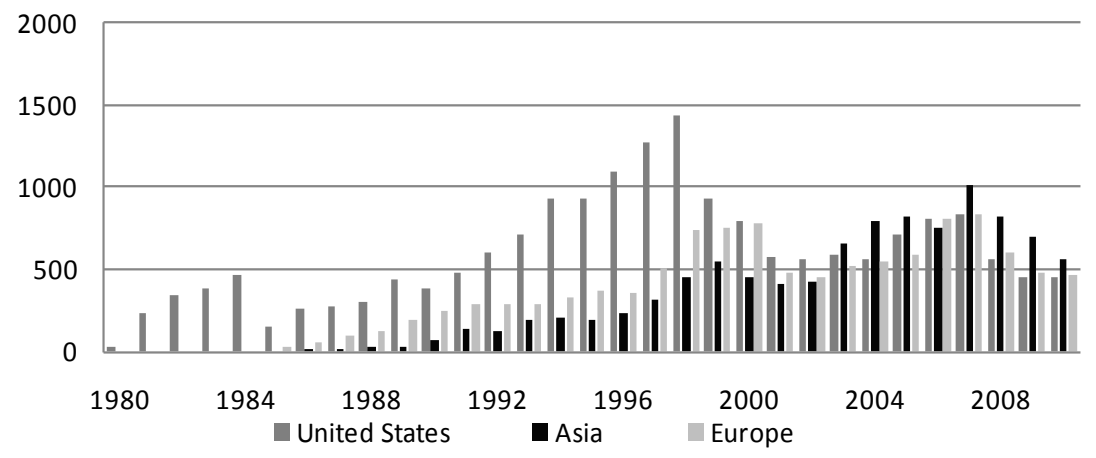

Figure 1. Global financial mergers amount in the EU, the US and Asia; Notes: The data sources from SDC platinum database from thomson financial. 
Pakistan, Philippines, South Korea, Turkey and Vietnam, and six from Asia country. Therefore, Asian financial markets are viewed by potential acquirers as virgin markets, compared to the US and the EU (Shih [4]). Then we would like to investigate how the merger can create the synergy after the merger in Asia bank market, which is a high economic growth nation. Table 1 shows the participants in the top ten global bank mergers from 1997 to 2007, ranked according to the value of the transaction, mainly from US and three from Japan.

Most of literature has focused on two main aspects: the effect of merger announcement and post-merger performance. The first line of research has focused on the stock market on the effect of merger announcement. Cybo-Ottone and Murgia [5] investigated a sample of acquisitions announced in European market from 1988 to 1997. They found the target has significantly positive abnormal returns and the acquirer has insignificant abnormal returns. Hagendorff et al. [6] focused on a more recent time period, from 1996 to 2004, and found different results from the previous studies that the acquirers' return was significantly positive. Moreover, they also suggested that the recent mergers may be qualitatively different from the early mergers and provide more relevant to likely future takeovers. However, the above studies just examined American or European bank M\&As. Therefore, we would like to examine Asian bank M\&As.

The second line of research had focused on the acquirers' performance post-merger, Weassess post-merger performance from the market performance and the operating performance. In the market performance, the handful studies found that bank mergers accrued significant stock market valuation gain after the merger (Diaz, Olalla and Azofra [7]; DeLong and DeYoung [8]). Resti and Siciliano [9] compared accounting-based with stock price-based performance measures for a sample of Italian banks over the period 1992-1997. On average

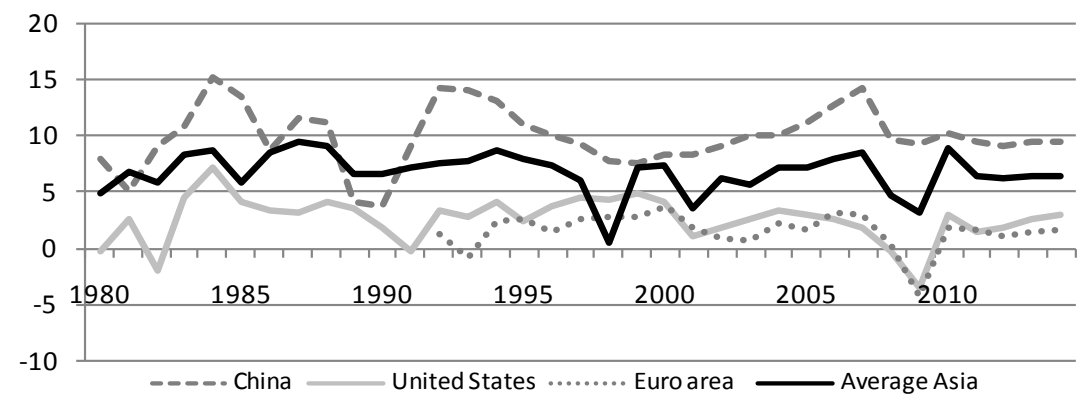

Figure 2. The real GDP growth rates in the EU, the US, China and Asia 1980-2014; Notes: 2011, 2012, 2013 and 2014 is expected. The data sources from International Monetary Fund, September 2011. Average Asia is including Newly Industrialized Asian and Economies and Developing Asia.

Table 1. The top ten merger deals of the world in transaction value.

\begin{tabular}{clcccc}
\hline $\begin{array}{c}\text { Date } \\
\text { Announced }\end{array}$ & \multicolumn{1}{c}{ Target Name } & $\begin{array}{c}\text { Target } \\
\text { Nation }\end{array}$ & \multicolumn{1}{c}{$\begin{array}{c}\text { Acquirer Name } \\
\text { Asquirer } \\
\text { Nation }\end{array}$} & $\begin{array}{c}\text { Value of Transaction } \\
\text { (US \$mil) }\end{array}$ \\
\hline 1998/4/13 & BankAmerica Corp & US & NationsBank Corp, Charlotte, NC & US & 61633.4 \\
1998/6/8 & Wells Fargo, San Francisco, CA & US & Norwest Corp, Minneapolis, MN & US & 34352.64 \\
$1999 / 8 / 20$ & Dai-Ichi Kangyo Bank Ltd & Japan & Fuji Bank Ltd & Japan & 40096.64 \\
$1999 / 10 / 13$ & Sakura Bank Ltd & Japan & Sumitomo Bank Ltd & Japan & 45494.37 \\
$1999 / 11 / 29$ & National Westminster Bank PLC & UK & Royal Bank of Scotland Group & UK & 38412.86 \\
2003/10/27 & FleetBoston Financial Corp, MA & US & Bank of America Corp & US & 49260.63 \\
2004/1/14 & Bank One Corp, Chicago, IL & US & JPMorgan Chase \& Co & US & 58663.15 \\
2005/2/18 & UFJ Holdings Inc & Japan & Mitsubishi Tokyo Financial Grp & Japan & 41431.03 \\
2005/6/30 & MBNA Corp & US & Bank of America Corp & US & 35810.27 \\
$2006 / 8 / 26$ & San Paolo IMI SpA & Italy & Banca Intesa SpA & Italy & 37624.24 \\
\hline
\end{tabular}

Notes: The financial industry sector of the ten top merger deals all is commercial banks and bank holding companies. The data sources from SDC Platinum database from Thomson Financial. 
the performance of Italian banks found a positive market prices changed effects after the acquisition. Houston et al. [10] found no conclusive evidence that the US banks acquirer creates value after the merger between 1985 and 1996.

In the operating performance, the previous studies of the US and the EU bank mergers assumed that the merger was driven by efficiency and profit ability issues. DeLong and DeYoung [8] examined the long-term financial performance of 216 M\&A of the US banking companies between 1987 and 1999 and found that the merger increased long-term ROA and improved the efficiency during the first years of their study, whereas, in the later years, whether the merger was international or whether payment was made in stock tended to have a great effect on performance. Diaz, Olalla and Azofra [7] analyzed a sample of 181 merger transactions from 1993 to 2000 in Europe, and found an increase in the acquirers' long-term profitability. The efficiency gained in Europe may be rather different from those in the US.

Altunbas and Marqués [3] separated their sample into domestic and cross-border merger in the EU bank industry, and examined the impact of banks' strategic similarities of the target and the acquirer on post-merger performance. This model related changes on post-merger performance to a set of strategic indicators and a set of control variables. The documented post-mergers have resulted in improved performance, particularly in the case of cross-border merger. And only efficiency and deposit strategies were performance-enhancing for both domestic and cross-border merger. Knapp et al. [11] analyzed the impacts of mean reversion on the evaluation of post-merger performance, with data based on 80 material global mergers in bank holding company from the period 1987 to 1998. One elucidation of mean reversion was the basic economic argument that competitive force would bring to equality in the rates of return in across the equity in the long-term, and calculated for the change of 1-, 2-, 3-, 4-, 5-, and 6-year's duration for each of the years. The research concluded that there were insignificant improvements in ROA and ROE in post-merger five years. But after adjustment for the mean reversion trend, they found the opposite result.

The previous studies usually analyzed the banks’ performance by two main measures. One measure is via accounting ratios of performance (such as ROA) or productive efficiency indicators (such as Efficiency) (e.g., Hagendorff and Keasey [12]; Koetter [13]; Behr and Heid [14]). Hagendorff and Keasey [12] compared bank mergers in the US and the EU by accounting ratio between 1996 and 2004 and found that the US banks focus on revenue generation post-merger, although this does not result in improving performance as cost increases. Koetter [13] found that German bank mergers during the 1990's were successful in improving cost efficiency, and cost efficiency gained took up to seven years to fully materialize. Behr and Heid [14] also found an evidence result of cost efficiency improvements in German banks after the merger between 1995 and 2000.

The majority measure of studies is by using event study. It based on changes in stock market prices around the merger periods. These studies typically try to ascertain whether the announcement of bank mergers creates shareholder value (normally in the form of cumulative abnormal t returns, CAR) for the shareholders of the target, the acquirer and/or the combined entity (e.g., Campa and Hernando [15]; Scholtens and De Wit [16]). Campa and Hernando [15] found that the shareholders of the target experiences a substantial gain in CAR from the merger but that shareholder of the acquirer experiences a loss in abnormal returns. Scholtens and De Wit [16] further found that the difference of CAR between the target and the acquirer were more significant in the US than in the EU. Berger and DeYoung [17] found that the acquirer holds significant increasing control, and was consistent with increased bank mergers. They also concluded that the distance has a negative effect on cost, profit, managerial control in banking.

As reviewed above, most of literature analyzed the effect of the merger on bank's performance in the short-term. To contrast with the above literature, we investigate the acquirers' post-merger performance in the long-term. We employ the Buy-and-Hold Abnormal Returns (BHAR) to calculate the long-term performance during post-merger periods. If BHAR is larger than zero or equal to zero, there is significant persistence in post-merger period. There are some studies used BHAR to calculate the long-term performance. Liu et al. [18] investigated the long-term recovery experience of US commercial banks that received capital infusions from the Troubled Asset Relief Program (TARP) funds distributed to distressed banks under the Capital Purchase Program (CPP). They found CPP banks experienced economically significant BHAR. They concluded that TARP was successful in fostering the financial and stock price recoveries of CPP banks. However, the most frequently used BHAR to define the long-term performance is the firm mergers (Dutta and Jog [19]). Dutta and Jog [19] investigated the long-term abnormal returns of Canadian acquiring firms in the post-event period by using 1300 M\&A events from 1993 to 2002, and revealed a insignificant BHAR for 1300 Canadian acquirers. 
In this paper, we examine the long-term performance of Asian acquiring banks after the merger by using 293 deals from 1997 to 2007 particularly commercial bank and bank holding company. This paper contributes to the literature in several aspects. First, we examine whether the acquirer can improve the long-term performance after the merger and persist for 36 months by using the Buy-and-Hold Abnormal Returns (BHAR). Second, we verify whether the deal attribute has a significant correlation with the long-term performance. Third, we would like to find if the operating indicator can affect the long-run performance and have a significant correlation with long-term stock returns. Fourth, we further investigate the effects of the deal attribute on the operating indicator, and find if the effect of the deal attribute can be decreased in the long-term. Finally and more importantly, we compare our results with the long-run performance and the previous studies of the US and the EU.

The remainder of this paper is organized as follows. In Section 2, we describe our empirical methodology including data, sample, BHAR, as well as the regression models used to estimate the long-run banks performance. In Section 3, we present and discuss our empirical results. In Section 4 we conclude.

\section{Methodology}

\subsection{Data and Sample}

The data of merged banks were from the SDC Platinum database from Thomson Financial. The accounting data for each of the merged banks were taken from Data Stream. To be included in the sample, a merger must have been announced between 1997 and 2007 in Asia, because the focus of this study is in the bank merger occurring after the Asian Financial Crisis. This was an excellent time for aggressive merger acquisitions because of the vast number of banks with many branches that were undervalued or in distress. However, we investigate the long-termperformancein3 years (36 months); the accounting data must until to 2010. We begin with an original sample of 17804 deals in Table 2. We eliminate cases that cannot meet the following criteria:

1) The target in Asia.

2) Both the target and acquirer are commercial bank and bank holding company.

3) The target was located in one of the 12 Asian nations ranked highest in M\&A frequency by preliminary observation: China, Hong Kong, India, Indonesia, Japan, Malaysia, Philippines, Singapore, South Korea, Taiwan, Thailand, and Vietnam.

Table 2. Mergers in the financial industry from 1997 to 2007.

\begin{tabular}{ccccccc}
\hline Year & $\begin{array}{c}\text { Number } \\
\text { of deals }\end{array}$ & $\begin{array}{c}\text { Domestic } \\
\text { Mergers }\end{array}$ & $\begin{array}{c}\text { The same } \\
\text { Industry Sector }\end{array}$ & $\begin{array}{c}\text { Number of CB } \\
\text { and BHC }\end{array}$ & $\begin{array}{c}\text { Average Value of } \\
\text { Transaction (US\$ mil) }\end{array}$ & $\begin{array}{c}\text { Max Value of } \\
\text { Transaction (US\$ mil) }\end{array}$ \\
\hline 1997 & $743(4.17 \%)$ & $526(70.79 \%)$ & 347 & 99 & 76.67 & 3017.63 \\
1998 & $1065(5.98 \%)$ & $700(65.73 \%)$ & 437 & 159 & 53.867 & 1300 \\
1999 & $1504(8.45 \%)$ & $1090(72.47 \%)$ & 650 & 248 & 242.37 & 45494.36 \\
2000 & $1200(6.74 \%)$ & $869(72.42 \%)$ & 573 & 196 & 148.39 & 14983.74 \\
2001 & $1195(6.71 \%)$ & $857(71.72 \%)$ & 565 & 177 & 97.87 & 5679.7 \\
2002 & $1428(8.02 \%)$ & $1105(77.38 \%)$ & 706 & 167 & 55.22 & 2932.53 \\
2003 & $1931(10.85 \%)$ & $1504(77.89 \%)$ & 913 & 183 & 64.52 & 16650.2 \\
2004 & $2154(12.1 \%)$ & $1673(77.67 \%)$ & 1002 & 175 & 69.56 & 29261.48 \\
2005 & $2084(11.71 \%)$ & $1546(74.18 \%)$ & 980 & 194 & 113.23 & 41431.03 \\
2006 & $2034(11.42 \%)$ & $1503(73.89 \%)$ & 952 & 188 & 89.39 & 10731.6 \\
2007 & $2466(13.85 \%)$ & $1821(73.84 \%)$ & 1120 & 202 & 112.64 & 8976.57 \\
\hline Total & $17804(100 \%)$ & $13194(74.11 \%)$ & 8245 & 1988 & &
\end{tabular}

Notes: The data sources rom SDC Platinum database from Thomson Financial. The financial industry sector is categorized by definition of SDC Platinum database from Thomson Financial includes (1) Commercial Banks and Bank Holding Companies (2) Savings and Loans, Mutual Savings Banks (3) Credit Institutions (4) Real Estate, Mortgage Bankers and Brokers (5) Investment and Commodity Firms/Dealers/Exchanges (6) Insurance (7) Other Finance. The same industry sector: the number of deals which both targets and acquirers are from same industry sector. The parentheses show the ratio of the years to total number of deals. 
4) All the financial statements are available from DataStream.

5) The acquirer still operating in 2010.

Our final sample consists of 293 commercial bank and bank holding company in Asia, of which 183 were domestic and 110 were cross-border. We concentrate on the merger involving Asia commercial bank and bank holding company because there been a great number of mergers at this level, and we assess the effects of a unique financial product market on performance.

\subsection{Sample Description}

Panel A of Table 3 shows the numbers and values of domestic and cross-border M\&A transactions in the Asian financial industry between 1997 and 2007, classified by year. The classification reveals that 62.46\% (183 deals) of the transactions were domestic merger. We find the number of merger deals gains after the Asian Financial Crisis (1997-1999), from 10 deals (3.41\%) to 42 deals (14.33\%). The international merger is increased slowly from 2005. However, the average transaction value achieves US \$2,822.21 dollars in 2005; it may be caused by the increased experienced acquirers. Also, the amount of 2006 and 2007 increased due to the trend of globalization.

Table 3. Numbers and values of M\&A transactions classified by year and country.

\begin{tabular}{|c|c|c|c|c|c|c|}
\hline Year & \multicolumn{2}{|c|}{ Number of deals } & Domestic Mergers & \multicolumn{2}{|c|}{$\begin{array}{c}\text { Average Value of Transaction } \\
\text { (US\$ mil) }\end{array}$} & $\begin{array}{l}\text { Max Value of Transaction } \\
\text { (US\$ mil) }\end{array}$ \\
\hline \multicolumn{7}{|c|}{ Panel A: Sorted by Year } \\
\hline 1997 & \multicolumn{2}{|l|}{$10(3.41 \%)$} & $4(40 \%)$ & \multicolumn{2}{|c|}{44.46} & 124.74 \\
\hline 1998 & \multicolumn{2}{|l|}{$14(4.78 \%)$} & $10(71.43 \%)$ & \multicolumn{2}{|c|}{301.94} & 933.28 \\
\hline 1999 & \multicolumn{2}{|l|}{$32(10.92 \%)$} & $23(71.88 \%)$ & \multicolumn{2}{|c|}{149.85} & 847.08 \\
\hline 2000 & \multicolumn{2}{|l|}{$42(14.33 \%)$} & $30(71.43 \%)$ & \multicolumn{2}{|c|}{159.16} & 1319.94 \\
\hline 2001 & \multicolumn{2}{|l|}{$20(6.83 \%)$} & $12(60 \%)$ & \multicolumn{2}{|c|}{566.98} & 3753.9 \\
\hline 2002 & \multicolumn{2}{|l|}{ 24(8.19\%) } & $19(9.17 \%)$ & \multicolumn{2}{|c|}{36.73} & 95.67 \\
\hline 2003 & \multicolumn{2}{|l|}{$25(8.53 \%)$} & $18(72 \%)$ & \multicolumn{2}{|c|}{132.46} & 615.62 \\
\hline 2004 & \multicolumn{2}{|l|}{ 25(8.35\%) } & $12(48 \%)$ & \multicolumn{2}{|c|}{712.22} & 2125.66 \\
\hline 2005 & \multicolumn{2}{|l|}{ 29(9.9\%) } & $11(37.93 \%)$ & \multicolumn{2}{|c|}{2822.21} & 41431.03 \\
\hline 2006 & \multicolumn{2}{|l|}{$37(12.63 \%)$} & $23(62.16 \%)$ & \multicolumn{2}{|c|}{1067.42} & 10731.6 \\
\hline 2007 & \multicolumn{2}{|l|}{$35(11.95 \%)$} & $21(60 \%)$ & \multicolumn{2}{|c|}{277.73} & 1874.93 \\
\hline Total & \multicolumn{2}{|l|}{$293(100 \%)$} & 183(62.46\%) & \multirow{2}{*}{\multicolumn{2}{|c|}{$\begin{array}{cc}\text { Domestic Mergers } & \text { Average Value of } \\
\text { Transaction (US\$ mil) }\end{array}$}} & \\
\hline Area & Number of deals & Target Nation & Number of deals & & & $\begin{array}{c}\text { Max Value of } \\
\text { Transaction (US\$ mil) }\end{array}$ \\
\hline \multicolumn{7}{|c|}{ Panel B: Sorted by Country } \\
\hline \multirow{4}{*}{$\begin{array}{l}\text { North } \\
\text { Asia }\end{array}$} & \multirow{4}{*}{80} & China & $30(10.24 \%)$ & $2(6.67 \%)$ & 425.42 & 2,500 \\
\hline & & Hong Kong & $14(4.78 \%)$ & $10(71.43 \%)$ & 384.8 & 1319.95 \\
\hline & & South Korea & $18(6.14 \%)$ & $7(38.89 \%)$ & 610.78 & 3277.6 \\
\hline & & Taiwan & $18(6.14 \%)$ & $13(72.22 \%)$ & 583.93 & 1547.94 \\
\hline \multirow{2}{*}{$\begin{array}{l}\text { Asia- } \\
\text { Pacific }\end{array}$} & 58 & India & $27(9.22 \%)$ & 25(92.59\%) & 73.3 & 168.38 \\
\hline & 50 & Indonesia & $31(10.58 \%)$ & $7(22.58 \%)$ & 15.36 & 70.43 \\
\hline Japan & 87 & Japan & $87(29.69 \%)$ & 85(97.7\%) & 1762.86 & 41431.03 \\
\hline & & Malaysia & $11(3.75 \%)$ & $8(72.73 \%)$ & 224.69 & 474.52 \\
\hline & & Philippines & $22(7.51 \%)$ & $12(54.55 \%)$ & 77.9 & 291.9 \\
\hline $\begin{array}{l}\text { Southeast } \\
\text { Asia }\end{array}$ & 68 & Singapore & $7(2.39 \%)$ & $6(85.71 \%)$ & 1284.82 & 3753.91 \\
\hline & & Thailand & $18(6.14 \%)$ & $8(44.44 \%)$ & 109.97 & 319.33 \\
\hline & & Vietnam & $10(3.41 \%)$ & $0(0 \%)$ & 21.38 & 27 \\
\hline Total & 293 & & $293(100 \%)$ & $183(62.46 \%)$ & & \\
\hline
\end{tabular}

Notes: The data sources from SDC Platinum database from Thomson Financial. The parentheses show the percentage. 
Panel B of Table 3 shows the numbers and values of domestic and cross-border M\&A transactions classified by country. The sample comes primarily from Japan and North Asia. Japan must be evaluated separately because it has the most experiences with M\&A and it is the only country in our sample that can be considered developed. There are 87 deals (29.69\%) from Japan account for the majority of the transactions in the sample, followed by 31 deals (10.58\%) from Indonesia and 30 deals (10.24\%) from China. The proportions of domestic merger for Japan, India, Singapore, Taiwan, Hong Kong and Philippines are 97.70\%, 92.59\%, 85.71\%, 72.22\%, $71.43 \%$ and $54.55 \%$, respectively. Note that the highest proportions (93.33\%) of international merger in China because many acquirers in the deals are from Hong Kong, a special administrative region belong to China. The rest proportions of international merger in Indonesia and Thailand may have resulted from the deregulation in their financial service industries after the Asian financial Crisis. The average values for transactions varied significantly by region within their countries. The highest values are for Japan (US \$1,762.86 dollars for transactions), following by Singapore (US $\$ 1284.82$ dollars for transactions).

Panel A of Table 4 classifies the numbers and values of domestic and cross-border M\&A transactions as a function if the number of transactions. The classification reveals that $81.23 \%$ of the transactions were initiated by an active acquirer (frequency of mergers more than 2 times per year). The percentages of mergers that are domestic rather than international are 83.64\% if 1 time, 82.81\% if $2-4$ times, and $28.18 \%$ if more than 5 times. Note that the deals announced by the more active acquirer (more than 5 times per year) are most frequency international (71.82\%), and have the highest average value (US \$1,060.26 dollars for transactions). Cross-border merger is more complex than domestic merger because they involve two different regulatory environments sets of customer expectations and national cultures. The more risk it faces, the more profitable it is.

Panel B of Table 4 classifies the numbers and values of M\&A transactions by acquirer's rations. There reveals that the majority of M\&A deals originated in Asia (220 deals, 75.09\%), and the transaction values is US $\$ 294.69$ dollars. During the last decade, there has been an extensive financial integration in Asia. The other aggressive acquirers were from the US \& Canada and European, where the financial industries are relatively mature and opportunities for organic growth are limited. The deals of acquirer region for US \&Canada and European are 22 deals (7.51\%) and 19 deals (6.48\%), respectively. The highest transaction value happened in Japan with US $\$ 41,431.03$ dollars for transactions. Table 5 shows that the numbers and values of M\&A transactions classified by transaction value. The vast majority of these transactions (224 deals, $76.45 \%)$ are valued at less than $\$ 100$ million. Only in Singapore and Malaysia the majority of the transactions are larger than $\$ 100$ million. Those relatively low Asian transaction values imply that, in Asia, financial integration through mergers is considered to be a bargain, especially in the countries whose banks have a relatively high proportion of non-performing loans.

Table 4. Numbers and values of M\&A transactions classified by frequency and the acquirers' nations.

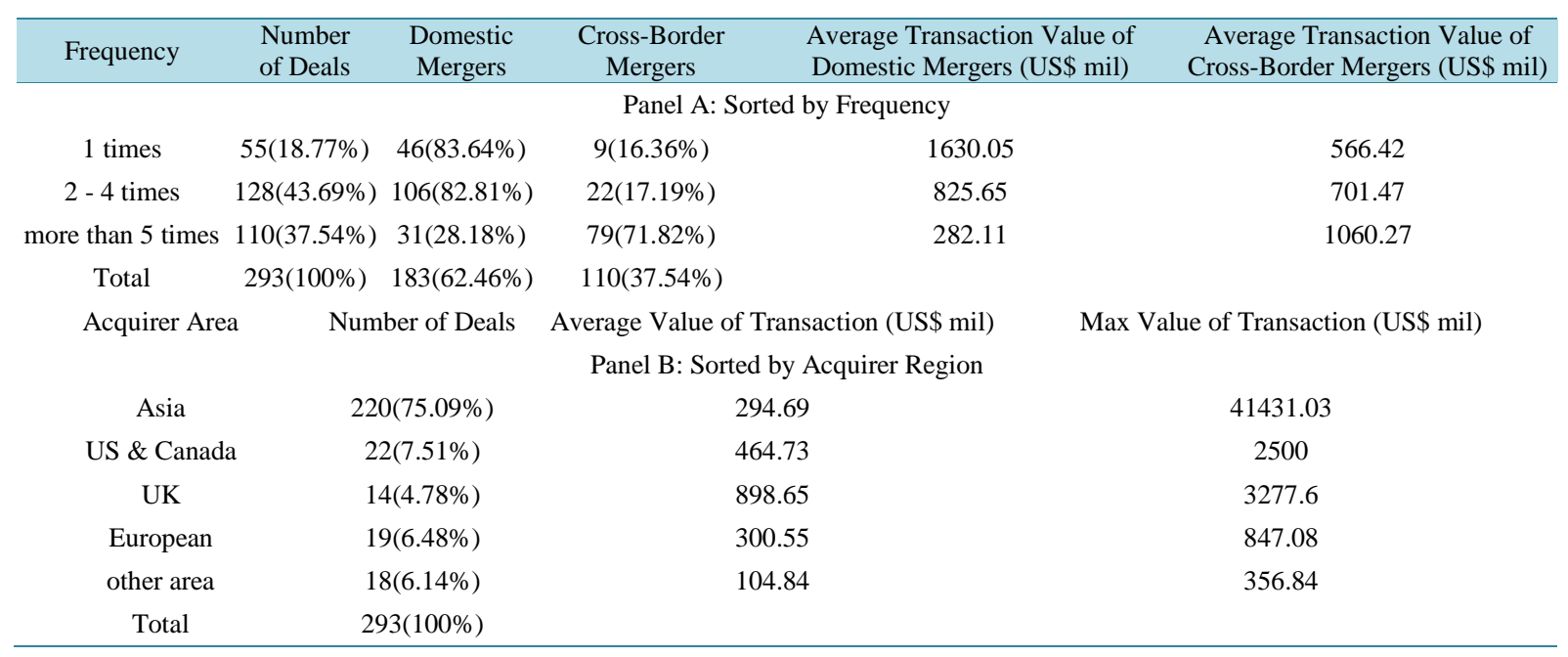

Notes: The data sources from SDC Platinum database from Thomson Financial. Panel A shows the division of times of launching mergers by specific acquirer from 1997 to 2007. Domestic Merger is defined as the transaction involves two commercial banks or bank holding companies of the same country. Cross-Border Merger is defined as the transaction involves two commercial banks or bank holding companies of the different countries. The parentheses show the percentage. 
Table 5. Numbers and values of M\&A transactions classified by transaction value.

\begin{tabular}{cccc}
\hline \multirow{2}{*}{ Area } & Target Nation & Number of Transaction Value $\leq$ US\$100 mil. & Number of Transaction Value > US\$100 mil. \\
\hline \multirow{2}{*}{ North Asia } & China & $21(70 \%)$ & $9(30 \%)$ \\
& Hong Kong & $7(50 \%)$ & $7(50 \%)$ \\
& South Korea & $11(61.11 \%)$ & $7(38.89 \%)$ \\
Asia-Pacific & Taiwan & $11(61.11 \%)$ & $7(38.89 \%)$ \\
& India & $26(96.3 \%)$ & $1(3.7 \%)$ \\
Japan & Japan & $31(100 \%)$ & $0(0 \%)$ \\
& Malaysia & $66(75.86 \%)$ & $21(24.14 \%)$ \\
& Philippines & $5(45.45 \%)$ & $6(54.55 \%)$ \\
Southeast Asia & Singapore & $20(90.91 \%)$ & $2(9.09 \%)$ \\
& Thailand & $2(28.57 \%)$ & $5(71.43 \%)$ \\
& Vietnam & $14(77.78 \%)$ & $4(22.22 \%)$ \\
& & $10(100 \%)$ & $0(0 \%)$
\end{tabular}

Notes: The data sources from SDC Platinum database from Thomson Financial. The parentheses show the percentage.

\subsection{Empirical Model}

In this section, we illustrate the empirical model. We introduce BHAR methodology to examine the long-term performance of the acquiring banks. We identify three biases in test statistics based on abnormal returns calculated (Barber and Lyon [20]). These three biases including:

- new listing bias, which arises because in event studies of long-run abnormal returns, sampled firms generally have a long post-event history of returns, while firms that constitute the index (or reference portfolio) typically include new firms that begin trading subsequent to the event month.

- rebalancing bias, which arises because the compound returns of a reference portfolio, such as an equally weighted market index, are typically calculated assuming periodic (generally monthly) rebalancing, while the returns of sample firms are compounded without rebalancing.

- skewness bias, which arises because long-run abnormal returns are skewed.

We define BHAR as the value of holding a long position in market index return of the acquirer bank after the merger is completed. The equation is stated below, and the MSCI AC ASIA index is used to measure the benchmark in this paper.

$$
B H A R_{i, 1, T}=\prod_{t=1}^{T}\left(1+R_{i, t}\right)-\prod_{t=1}^{T}\left(1+R_{B, t}\right)
$$

where $R_{i, t}$ is the monthly return of the sample bank $i$ in month $t$ during T-month post-merger period, with the initial announcement month being defined as month 0 ; and $R_{B, t}$ is the monthly return of the benchmark over the same period (Dutta and Jog [19]).

BHAR is considered in the regression models by rolling every 36-month from 1997 to 2007. Because it can eliminate the problem of cross-sectional dependence among samples banks (Gregory [21]). If the rolling BHAR is larger than zero or equal to zero, we call there is significantly persistence in post-merger period. After determining the rolling BHAR was significant, we focus on the variables which we set might affect the rolling BHAR.

Variables are separated the deal attribute from the acquirer bank's operating indicators. The deal attribute includes domestic merger, transaction value, frequency of mergers and the relative assets of the target and acquirer. The operating indicator includes (1) ROA, (2) Efficiency, (3) Loan ratio, (4) Risk, (5) Capital ratio, (6) Deposit ratio and (7) Assets growth. The detail explanation of variables is discussed in 2.4. We calculate the operating 
indicator by the average between the rolling periods from 1997 to 2007. The equation is stated below.

$$
\text { Operating Indicator }{ }_{(i, t+1, t+36)}=\frac{\left(O I_{i, t+12}+O I_{i, t+24}+O I_{i, t+36}\right)}{3}
$$

where Operating Indicator $_{(i, t+1, t+36)}$ is the average in operating indicator $i$ in the month $t$; and $O I_{i, t+12}, O I_{i, t+24}$ and $\mathrm{OI}_{i, t+36}$ are the scores for the operating indicator $i$ at $\mathrm{t}+12, \mathrm{t}+24$ and $\mathrm{t}+36$.

To be robustness our study, we setup there regression models. Model 1 investigates the correlation between the deal attribute and long-term abnormal returns of the acquirer. We add the operating indicator into model 2, such that we are able to find the interaction between the deal attribute and the operating indicator and whether the interaction can create the higher long-term synergy. In model 3, we add the dummy variable for the effect of the Asian Financial Crisis, which was happened in 1997 to 1998. The regression models are as follows:

$$
\begin{aligned}
\text { Model 1: } & \text { Rolling } \operatorname{BHAR}_{(i, T+1, T+36)}=\beta_{0}+\beta_{1} x_{1, i}(\text { Frequency of merger }) \\
& \left.+\beta_{2} x_{2, i}(\text { Domestic merger })+\beta_{3} x_{3, i}(\text { Transaction value })+\beta_{4} x_{4, i} \text { (Relative size }\right)+\varepsilon_{i} \\
\text { Model 2 } & \text { Rolling BHAR }{ }_{(i, T+1, T+36)}=\beta_{0}+\beta_{1} x_{1, i}(\text { Frequency of merger }) \\
& +\beta_{2} x_{2, i}(\text { Domestic merger })+\beta_{3} x_{3, i}(\text { Transaction value })+\beta_{4} x_{4, i}(\text { Relative size }) \\
& +\beta_{5} x_{5, i}(\mathrm{ROA})+\beta_{6} x_{6, i}(\text { Efficiency })+\beta_{74} x_{7, i}(\text { Loan ratio })+\beta_{84} x_{8, i}(\text { Risk }) \\
& +\beta_{9} x_{9, i}(\text { Capital ratio })+\beta_{10} x_{10, i}(\text { Deposit ratio })+\beta_{1140} x_{11, i}(\text { Assets growth })+\varepsilon_{i} \\
\text { Model 3 } & \text { Rolling BHAR }(i, T+1, T+36)=\beta_{0}+\beta_{1} x_{1, i}(\text { Frequency of merger }) \\
& +\beta_{2} x_{2, i}(\text { Domestic merger })+\beta_{3} x_{3, i}(\text { Transaction value })+\beta_{4} x_{4, i}(\text { Relative size }) \\
& +\beta_{5} x_{5, i}(\text { ROA })+\beta_{6} x_{6, i}(\text { Efficiency })+\beta_{74} x_{7, i}(\text { Loanratio })+\beta_{84} x_{8, i}(\text { Risk }) \\
& +\beta_{9} x_{9, i}(\text { Capital ratio })+\beta_{10} x_{10, i}(\text { Deposit ratio })+\beta_{1140} x_{11, i}(\text { Assets growth }) \\
& +\beta_{12} x_{12, i}(\text { Downturn })+\varepsilon_{i}
\end{aligned}
$$

To further investigate the effects of the deal attribute on the operating indicator, the regression analysis are performed on the variables which are significant in the 36-month period. We introduce the frequency of mergers, domestic merger, downturn and dummy, four dummy variables into the regression analysis. The dummy variable is added to represent the transaction happened in 1997. Additionally, transaction value and relative size are also added to this regression analysis. We use the following model for this regression analysis.

$$
\begin{aligned}
& \text { Operating indicators }_{(i, T+1, T+36)}=\beta_{0}+\beta_{1} x_{1, i}(\text { Frequency of merger })+\beta_{2} x_{2, i}(\text { Domestic merger }) \\
& \left.+\beta_{3} x_{3, i} \text { (Transaction value }\right)+\beta_{4} x_{4, i}(\text { Relative size })+\beta_{5} x_{5, i}(\text { Downturn })+\beta_{6} x_{6, i}(\text { Dummy })+\varepsilon_{i}
\end{aligned}
$$

\subsection{Definition of the Explanatory Variables}

The deal attribute includes frequency of mergers, domestic merger, transaction value and the relative assets of the target and acquirer. The operating indicator include (1) ROA, (2) Efficiency, (3) Loan ratio, (4) Risk, (5) Capital ratio, (6) Deposit ratio and (7) Assets growth. The explanation of variables stated in Table 6.

We adopt the operating variable from the previous studies. First, ROA is measured as net income to average total asset. The bank is a high leverage financial institution, therefore ROA have more explanatory than ROE comparatively. Second, the most common way to calculate efficiency is the cost to net income. It's net income to be generated from each dollar of cost. Third, loan ratio is measured as the ratio of net loan to total assets, which takes into account the prominence of loan in banks' total assets. Risk is measured as the level of loan loss provisions divided by net interest revenues (Altunbas and Marqués [3]). Altunbas and Marqués [3] revealed signification negative in domestic merger for loan ratio and risk, but it is opposition in cross-border merger. They showed that's quite cost to integrate institutions which are heterogeneous in terms of their loan ratio for domestic deals. 
Table 6. Definition of the explanatory variables.

\begin{tabular}{ll}
\hline Variables & Definition \\
\hline Frequency of merger & $\begin{array}{l}=1, \text { if frequency of merger is } 1 \text { - } 4 \\
=0, \text { if frequency of merger }>5\end{array}$ \\
$\begin{array}{l}=1, \text { if the merging banks are from the same country } \\
=0, \text { otherwise }\end{array}$ & $\begin{array}{l}\text { Log(transaction value) } \\
\text { Transaction value }\end{array}$ \\
Relative size & Target total assets/Acquirer total assets \\
ROA & Net income/Average total assets \\
Efficiency & Total costs/Net income \\
Loan ratio & Net loans/Total assets \\
Risk & Loan loss provisions/Net interest revenues \\
Capital ratio & Total capital/Total assets \\
Deposit ratio & Total deposit/Total capital \\
Assets growth & (Total assets at $\mathrm{t}-$ total assets at $\mathrm{t}-1$ )/Total assets at $\mathrm{t}-1$ \\
Downturn & $=1$, if the merger happened in 1997 and 1998 \\
& $=0$, otherwise
\end{tabular}

Notes: The signal “*” indicated that the expected sign is uncertainty. The signal “+” (“-”) indicated that there is positive (negative) post-merger effect on the variables.

Fourth, capital ratio is measured as the ratio of equity to total assets. This variable becomes more important in recent years, considering a focal point of bank regulation. Altunbas and Marqués [3] also used this variable to verify post-merger performance and found that the better capital level make performance-enhancing indomestic merger. For cross-border merger, however, tend to lower performance. Since capital is used by banks to feature of asset quality, it seems to be more difficult for cross-border merger to integrate with different capital level. The deposit ratio is measured as the total deposit to total equity, as measures of bank performance. Cornett et al. [22] introduced the deposit ratio to determine whether post-IPO of bank dividend initiation or increase meaningfully affects the probability of ultimate acquisition as well as the average takeover premium paid in an acquisition. They showed lower deposit ratio after post-IPO.

Finally, assets growth was entered in Cheng et al.'s study [23], which used the 135 takeover banks from 1981 to 1986. They revealed assets growth was significant negative with value. In summary; most previous studies found a positive relationship between the merger activities and gained in indicator performance.

\subsection{Hypotheses}

Several studies show that the abnormal returns of the acquirer is significant positive in the long run after the merger in the US and the EU banks market. In this study, we assume that the long-run performance by using BHAR reveals a significant positive effect after the merger and can persist for 36-month. We also forecast that the effect of the deal attribute is decreases gradually as time goes on. Numerous studies find the positive reactions to the efficiency and ROA on post-merger performance. Then, we expect that both efficiency and ROA of the acquirer would indicate significant improvement in long-term performance. The rest operating indicator like loan ratio, risk, and capital ratio are expected to have significant positive result, too. Except for deposit ratio, it is expected to have significant negative effect on the long-run performance and the assets growth is expected to have no signification with long-run performance.

Finally, we compare our results with the long-run performance and the previous studies of the US and the EU. Additionally, we hypothesize that the effect were in influenced by the Asian Financial Crisis is significant.

\section{Empirical Results}

In this section, we document the result of our empirical models in long-term post-merger performance. First, we show the descriptive statistics of the explanatory variables of the operating indicator, and the result for BHAR 
over 36-, 48-, 60-month and rolling BHAR every 36-monthpost-merger between 1997 and 2007. Then, we discuss the result of the regression analysis. Subsequently, we document the regression analysis of the operating indicator on the deal attribute.

\subsection{Descriptive Statistics}

Table 7 reports the descriptive statistics of the operating indicator over 36-, 48-, 60-month and the rolling every 36-month from 1997 to 2007. Ideally, merging is not only a faster way for the acquirer to increase revenue than investments internally, but also typically less risky. Risk is significant decreased slightly in our result. In term of efficiency, the ratio is to save costs by eliminating overlapping operations and consolidating operations (Houston et al. [10]). Efficiency is decreased definitely after the merger. On average, the operating indicator shows a significant positive mean and median for three periods after post-merger and the rolling period.

\subsection{Buy-and-Hold Abnormal Returns}

The specification of t-statistics by using the Buy-and-Hold Abnormal Returns is presented in Table 8. BHAR is a significant negative in t-statistics which can confirm to the skewness biases. Additionally the skewness bias can ultimately be traced to the rebalancing biases. BHAR is $-23.5 \%$ over 48 -month, revealed a significant negative excess returns after the merger.Over36-month, although BHAR is $-10.1 \%$, but not significant, the maximum of BHAR is $131.8 \%$ and shows a high long-term abnormal returns. BHAR over 60 -month is $-13.9 \%$. It is higher than over 48-month. It may due to the reduced sample. Because the sample period is 1997 to 2007, we could not calculate the 60-mouth at 2006 and 2007 (The complete data in DataStream are only in 2010). Eventually, the rolling BHAR is $-13.7 \%$.

Table 7. Descriptive statistics of the explanatory variables of the operating indicator.

\begin{tabular}{cccccccccc}
\hline \multirow{2}{*}{ Variable } & \multicolumn{2}{c}{ 36-month } & \multicolumn{2}{c}{48 -month } & \multicolumn{2}{c}{60 -month } & \multicolumn{2}{c}{ Rolling 36-month } \\
\cline { 2 - 10 } & Mean & Med & Mean & Med & Mean & Med & Mean & Med \\
\hline ROA & $0.0039^{* * *}$ & $0.0037^{* * *}$ & $0.004^{* * *}$ & $0.0033^{* * *}$ & $0.0039^{* * *}$ & $0.003^{* * *}$ & $0.0042^{* * *}$ & $0.0031^{* * *}$ \\
Efficiency & $22.47^{* *}$ & 6.13 & $11.05^{* * *}$ & 6.79 & $10.10^{* * *}$ & 7.15 & $56.63^{* * *}$ & 5.81 \\
Loan ratio & $0.62^{* * *}$ & 0.64 & $0.62^{* * *}$ & 0.64 & $0.63^{* * *}$ & 0.64 & $0.63^{* * *}$ & 0.63 \\
Risk & $0.31^{* * *}$ & 0.19 & $0.30^{* * *}$ & 0.18 & $0.30^{* * *}$ & 0.18 & $0.24^{* * *}$ & 0.16 \\
Capital ratio & $0.12^{* * *}$ & 0.10 & $0.12^{* * *}$ & 0.10 & $0.11^{* * *}$ & 0.10 & $0.12^{* * *}$ & 0.10 \\
Deposit ratio & $8.25^{* * *}$ & 6.70 & $8.03^{* * *}$ & 6.66 & $8.90^{* * *}$ & 8.18 & $8.43^{* * *}$ & 7.23 \\
Assets growth & $0.08^{* * *}$ & 0.05 & $0.08^{* * *}$ & 0.05 & $0.07^{* * *}$ & 0.04 & $0.07 * * *$ & 0.03 \\
\hline
\end{tabular}

Note: The operating indicator is based on Table 6. Number of Observations Read $=76,67,51$ and 355 for each rows. *, **, and $* * *$ indicate statistical significance at 10\%, 5\%, and 1\% levels, respectively (Based on t-statistics).

Table 8. BHAR over 36-, 48-, 60-month and the rolling BHAR every 36-month period after the merger from 1997 to 2007 (Unit: \%).

\begin{tabular}{ccccccc}
\hline & Mean & Std Dev. & Med & Min & Max & $t$-Value \\
\hline BHAR $[\mathrm{t}+1, \mathrm{t}+36]$ & -10.1 & 0.558 & -15.9 & -109.1 & 131.8 & -1.58 \\
BHAR $[\mathrm{t}+1, \mathrm{t}+48]$ & $-23.5^{* * *}$ & 0.653 & -29.4 & -125.0 & 158.9 & -2.95 \\
BHAR $[\mathrm{t}+1, \mathrm{t}+60]$ & -13.9 & 0.707 & -9.5 & -164.9 & 149.8 & -1.4 \\
Rolling BHAR $[\mathrm{t}+1, \mathrm{t}+36]$ & $-13.7^{* * *}$ & 0.425 & -15.9 & -93.9 & 150.4 & -6.06 \\
\hline
\end{tabular}

Notes: "BHAR" is the Buy-and-Hold Abnormal Returns by using market returns. The benchmark is MSCI AC ASIA index. The rolling BHAR is rolling every 36-month from 1997 to 2007. There are 76, 67, 51 and 355 samples for 36-, 48-, 60-month and the rolling BHAR every 36-month period, respectively. BHAR is expressed in \%. *, **, and *** indicate statistical significance at $10 \%, 5 \%$, and $1 \%$ levels, respectively (Based on t-statistics). Standard errors are reported in parentheses. 
Because the result shows that BHAR is a significant negative, we speculate that it may because the acquirer cannot outperform the market. So, we only calculate the returns of the acquirer before minus the benchmark and call the Buy-and-Hold Returns (BHR). The equation is stated below.

$$
B H R_{i, 1, T}=\prod_{t=1}^{T}\left(1+R_{i, t}\right)
$$

where $R_{i, t}$ is the monthly return of the sample bank $i$ in month $t$ during T-month post-merger period, with the initial announcement month being defined as month 0 .

The result is presented in Table 9. We find BHR is significant and larger than $100 \%$ over three periods after the merger. It means that the return of the acquirer is increased but cannot outperform the market. Additionally, the rolling BHR every 36-monthalso reveals a significant positive result. Therefore, we can say that BHAR is influenced by the bench mark conclusively. Following the regression analysis, we will perform the both rolling BHAR and rolling BHR over a set of variables; analyze how the explanatory variable can affect the two independent variables in the long-term, and what different between the two regression results.

\subsection{Regression Results}

To rationalize our result, we make the correlation coefficient matrix of the explanatory variables. In general, the correlation coefficients are smaller than 0.4 , which means there are significant low correlations within the explanatory variables, and VIFs are less than 10 which prove that there is no multi collinear problem.

The regression results of the rolling BHAR every 36-month period on a set of variables shows at Table 10. And, we calculate the operating indicator by the average every rolling 36-month from 1997 to 2007. As expected in model 1 , while the result indicates that the frequency of mergers and relative ratio of the acquirer do not play a major role in influencing post-merger performance and domestic merger have a significant effect in the long run. Cross-border merger gain benefit for other synergies easier than domestic merger in Asia. Likewise, the results are in line with Altunbas and Marqués's result [3]. It also shows that the transaction values have significant negative effect with the long-run performance. In other words, the amount of transaction values could not be a determination of the long-run performance positively. The results are consistent with the previous studies. They found that the deal attribute were negative related or insignificant to the stock market returns (Campa and Hernando [15]). Additionally, local bank regulators forced domestic banks to merge as a way to reduce bank failure risk (Shih [4]). So it seemed that the domestic bank merger which is passive and forcing transactions have a negative effect on the long-run performance. The cross-border merger which is active transactions have a positive effect on the long-run performance. However, adjusted R-Squared has a low value in model 1 (0.0507), reveals the explanation of the deal attribute to long-run performance is insufficient. So, we adopt the operating indicator into model 2.

In model 2, the adjusted R-Squared is 0.16 , which is increased conspicuously. It reveals a higher explanation to long-run performance. The deal attribute are similar with model 1 . If the merger has a lower transaction value in cross-border merger, there is a positive effect with long-term performance. The result for ROA suggests a high size of asset disposition on the acquirer tends to positively affecting at the level of performance after post-merger. Despite most of the previous studies have found positive reactions to the efficiency on post-merger

Table 9. BHR over 36-, 48-, 60-month and the rolling BHR every 36-month period after the merger from 1997 to 2007 (Unit: \%).

\begin{tabular}{ccccccc}
\hline & Mean & Std Dev. & Med & Min & Max & $\mathrm{t}$-Value \\
\hline BHR $[\mathrm{t}+1, \mathrm{t}+36]$ & $100.1^{* * *}$ & 61.1 & 102.9 & 0.02 & 304.9 & 14.29 \\
BHR $[\mathrm{t}+1, \mathrm{t}+48]$ & $103.5^{* * *}$ & 62.7 & 93.1 & 9.7 & 254.7 & 13.52 \\
BHR $[\mathrm{t}+1, \mathrm{t}+60]$ & $112.4^{* * *}$ & 62.3 & 100.7 & 17.9 & 329.4 & 12.89 \\
Rolling BHR $[\mathrm{t}+1, \mathrm{t}+36]$ & $95.1^{* * *}$ & 52.1 & 85.1 & 0.02 & 304.9 & 34.37 \\
\hline
\end{tabular}

Notes: "BHR" is the Buy-and-Hold Returns by using market returns. The rolling BHR is rolling every 36-month from 1997 to 2007. There are 76, 67, 51 and 355 samples for 36-, 48-, 60-month and the rolling BHR every 36-month period, respectively. BHR is expressed in \%. *, **, and *** indicate statistical significance at $10 \%, 5 \%$, and $1 \%$ levels, respectively (Based on t-statistics). Standard errors are reported in parentheses. 
Table 10. Regression analysis of the rolling BHAR.

\begin{tabular}{|c|c|c|c|}
\hline Variables & Model 1 & Model 2 & Model 3 \\
\hline Frequency of merger & $-0.071(0.307)$ & $-0.053(0.47)$ & $-0.045(0.535)$ \\
\hline Domestic merger & $-0.124 *(0.089)$ & $-0.158 * *(0.014)$ & $-0.161^{* *}(0.012)$ \\
\hline Transaction value & $-0.062 * * *(0.0001)$ & $-0.044 * * *(0.001)$ & $-0.042 * * *(0.002)$ \\
\hline Relative size & $0.00(0.713)$ & $0.00(0.523)$ & $0.00(0.471)$ \\
\hline $\mathrm{ROA}[\mathrm{t}+1, \mathrm{t}+36]$ & & $20.542 * * *(0.004)$ & $21.056^{* * *}(0.003)$ \\
\hline Efficiency[t $+1, t+36]$ & & $0.639 *(0.098)$ & $0.67 *(0.083)$ \\
\hline Loan ratio $[t+1, t+36]$ & & $0.316 * * *(0.007)$ & $0.298 * * *(0.001)$ \\
\hline $\operatorname{Risk}[t+1, t+36]$ & & $0.127(0.146)$ & $0.129(0.141)$ \\
\hline Capital ratio[t $+1, t+36]$ & & $2.117^{* *}(0.014)$ & $2.092 * *(0.016)$ \\
\hline Deposit ratio $[\mathrm{t}+1, \mathrm{t}+36]$ & & $-0.034(0.195)$ & $-0.031(0.222)$ \\
\hline Assets growth $[t+1, t+36]$ & & $0.00(0.201)$ & $0.00(0.169)$ \\
\hline Downturn & & & $0.067(0.239)$ \\
\hline Intercept & $1.242^{* * *}(0.00001)$ & $0.15(0.545)$ & $0.116(0.644)$ \\
\hline Observations & 355 & 355 & 355 \\
\hline Adj R-Squared & 0.0507 & 0.16 & 0.1663 \\
\hline
\end{tabular}

Notes: The dependent variable are the Rolling BHAR relation to the performance of the MSCI AC ASIA index, every the 36-month between 1997 and 2007. We calculate the average in operating indicator in the rolling periods. P-value is reported in parentheses. *, **, and *** indicate statistical significance at $10 \%, 5 \%$, and $1 \%$ levels, respectively (Based on t-statistics).

performance, we find slightly improvement in efficiency at $10 \%$ level of significant based on t-statistics. Generally, most studies showed that different cost structures could experience a drop in performance after post-merger. This finding may be related to the US evidence showing that there is very little improvement in cost efficiencies after post-merger (DeYoung, 1997 [24]).

Capital ratio reveals a significant positive effect on the long-run performance-enhancing. Since capital ratio is considered as signal favorable asset quality for banks, it seems to be more explanatory for the long-run performance. Since the bank is a high liability industry as a result, capital ratio could not be higher. Loan ratio also reveals a significant positive effect on the long-term performance. The more money the bank loans, the more performance the bank makes. Both risk and deposit ratio have no significant effects on the long-run performance. And, assets growth have no significant negative effect on the long-run performance as expected, it probably come from the size of total asset for the acquirer after the merger do not changes after the merger.

Finally, we introduce dummy variables into model 3. The dummy variable is added for indicating the effects of the Asian Financial Crisis, the number of mergers that are international, and the relative assets of the merging partners. The result is in line with model 2, and there are no interactive effects in model 3 . The dummy variable is totally insignificant with the long-run performance. This means that even the Asian financial Crisis brings the amount of mergers, it does not result in the value for the acquirer after the merger.

The regression results of the rolling BHR every 36-month period on a set of variables shows in Table 11. And, we calculate the operating indicator by the average every rolling 36-month from 1997 to 2007. We investigate how BHR of the acquirer can be influenced by the deal attribute and the operating indicator after the merger. The result shows that adjusted R-Squared in model 4(0.0289) is lower than model 1(0.0507). However, domestic merger and transaction value like model 1 have a significant negative effect on BHR. Models5 and6 reveal a dissimilar result to models 2 and 3. Although there is a significant effect for ROA, our result also shows that risk and assets growth have a significant positive effect on the long-run returns. There reveals a significant positive effect on efficiency and capital ratio in model 2, but model 5documentsan opposite results.

In Table 10 and Table 11, we calculate the operating indicator by the average between the rolling periods 
Table 11. Regression analysis of the rolling BHR.

\begin{tabular}{|c|c|c|c|}
\hline Variables & Model 4 & Model 5 & Model 6 \\
\hline Frequency of merger & $-0.042(0.467)$ & $0.33(0.455)$ & $0.336(0.54)$ \\
\hline Domestic merger & $-0.061 * *(0.025)$ & $-0.064^{* * *}(0.0001)$ & $-0.052^{* * *}(0.0001)$ \\
\hline Transaction Value & $-0.025 *(0.069)$ & $-0.082 * * *(0.0001)$ & $-0.078^{* * *}(0.0001)$ \\
\hline Relative ratio & $0.00(0.308)$ & $0.00(0.226)$ & $0.00(0.273)$ \\
\hline $\mathrm{ROA}[\mathrm{t}+1, \mathrm{t}+36]$ & & $45.103^{* * *}(0.0001)$ & $45.922 * * *(0.0001)$ \\
\hline Efficiency[t + 1, t + 36] & & $0.00(0.232)$ & $0.00(0.273)$ \\
\hline Loan ratio[t + 1, $t+36]$ & & $0.34 * *(0.01)$ & $0.37 * *(0.01)$ \\
\hline $\operatorname{Risk}[t+1, t+36]$ & & $0.349^{* * *}(0.0001)$ & $0.352^{* * *}(0.0001)$ \\
\hline Capital ratio[t + 1, t + 36] & & $0.079(0.938)$ & $0.119(0.906)$ \\
\hline Deposit ratio[t + 1, $t+36]$ & & $0.00(0.994)$ & $0.002(0.893)$ \\
\hline Assets growth $[\mathrm{t}+1, \mathrm{t}+36]$ & & $0.902 * *(0.045)$ & $0.952 * *(0.035)$ \\
\hline Downturn & & & $0.107(0.51)$ \\
\hline Intercept & $0.026(0.688)$ & $1.016^{* * *}(0.001)$ & $0.960 * * *(0.001)$ \\
\hline Observations & 355 & 355 & 355 \\
\hline Adj R-Squared & 0.0289 & 0.2427 & 0.2462 \\
\hline
\end{tabular}

Notes: The dependent variable are the Rolling BHR every the 36-month between 1997 and 2007. We calculate the average in operating indicator in the rolling periods. P-value is reported in parentheses.*, **, and *** indicate statistical significance at $10 \%$, 5\%, and $1 \%$ levels, respectively (Based on t-statistics).

from 1997 to 2007. But, we find there is an irrational correlation effect between BHAR and operating indicator in Table 10, which means the former reveal a negative BHAR result but the later reveal a positive correlation effect on BHAR after the merger in the long run. We speculate that the Asia market is more focus on the improvement of the operating performance rather than the average of the operating indicator. So, we calculate the change in operating indicator every 36-month in the rolling periods instead of the average from 1997 to 2007 , and introduce it into the regression analysis of rolling BHAR. The equation is stated below.

$$
\Delta \text { Operating Indicator }{ }_{(i, t+1, t+36)}=O I_{i, t+36}-O I_{i, t+12}
$$

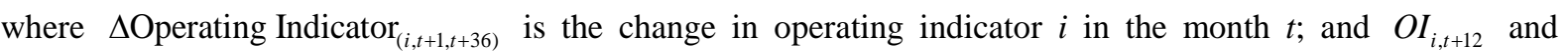
$O I_{i, t+36}$ are the scores for the operating indicator $i$ at $t+12$ and $\mathrm{t}+36$.

The result shows in Table 12, and is consistent with the result of BHAR. Except that ROA and risk reveal a significant positive effect on the long-run post-merger performance. However, the rest operating indicator shows an insignificant effect. We can say that the change in operating indicator in the rolling periods is more suitable than the average in operating indicator.

As same as Table 12, we also adopt the change in operating indicator into the regression analysis of rolling BHR. The regression results are showed in Table 13. First, we find that adjusted R-Squared is significantly higher than in models 5 and 6, and this reveals a higher explanation to long-run performance. Second, the deal attribute has a similar result as model 4 that there is significant negative effect on the long-run performance. Third, the operating indicator such as ROA, loan ratio, risk and capital ratio show a significant positive effect on the long-run returns, except for deposit ratio. It has a significant negative effect on the long-run returns, which is accord with our hypothesis. It means that when the amount of deposit dropped, the long-run returns of the acquirer can be better. After we compare Table 11 and Table 13, we find that if we do not consider whether the return of the acquirer can outperform the market, it shows a suitable with the change in operating indicator. The improvement of the operating indicator has a positive correlation with the long-run returns. 
Table 12. Regression analysis of the rolling BHAR with the changed operating indicator.

\begin{tabular}{ccc}
\hline Variables & Model 7 & Model 8 \\
\hline Frequency of merger & $-0.052(0.344)$ & $-0.052(0.345)$ \\
Domestic merger & $-0.087^{* *}(0.038)$ & $-0.086^{* *}(0.045)$ \\
Transaction Value & $-0.014^{* *}(0.2)$ & $-0.014^{* *}(0.209)$ \\
Relative ratio & $0.00(0.186)$ & $0.00(0.187)$ \\
$\Delta$ ROA $[\mathrm{t}+1, \mathrm{t}+36]$ & $22.678^{* * *}(0.0001)$ & $0.00(0.959)$ \\
$\Delta$ Efficiency[t $+1, \mathrm{t}+36]$ & $0.00(0.959)$ & $0.631(0.139)$ \\
$\Delta$ Loan ratio[t $+1, \mathrm{t}+36]$ & $0.629(0.169)$ & $0.163 * *(0.01)$ \\
$\Delta$ Risk[t $+1, \mathrm{t}+36]$ & $0.163 * *(0.01)$ & $0.02(0.185)$ \\
$\Delta$ Capital ratio[t $+1, \mathrm{t}+36]$ & $0.02(0.185)$ & $0.028(0.177)$ \\
$\Delta$ Deposit ratio[t $+1, \mathrm{t}+36]$ & $0.028(0.176)$ & $-0.043(0.771)$ \\
$\Delta$ Assets growth[t $+1, \mathrm{t}+36]$ & $-0.043(0.771)$ & $0.004(0.952)$ \\
Downturn & & $0.031(0.647)$ \\
Intercept & $0.032(0.608)$ & 355 \\
Observations & 355 & 0.1233 \\
Adj R-Squared & 0.1259 & $0.001)$ \\
\hline
\end{tabular}

Notes: The dependent variable are the Rolling BHAR relation to the performance of the MSCI AC ASIA index, every the 36-month between 1997 and 2007. We calculate the change in operating indicator in the rolling periods. P-value is reported in parentheses. *, **, and *** indicate statistical significance at $10 \%, 5 \%$, and $1 \%$ levels, respectively (Based on t-statistics).

Table 13. Regression analysis of the rolling BHR with the changed operating indicator.

\begin{tabular}{|c|c|c|}
\hline Variables & Model 9 & Model 10 \\
\hline Frequency of merger & $0.052(0.4)$ & $0.052(0.406)$ \\
\hline Domestic merger & $-0.164^{* *}(0.013)$ & $-0.17 * *(0.011)$ \\
\hline Transaction Value & $-0.04^{* * *}(0.001)$ & $-0.041^{* * *}(0.001)$ \\
\hline Relative ratio & $0.00(0.692)$ & $0.00(0.733)$ \\
\hline$\Delta \mathrm{ROA}[\mathrm{t}+1, \mathrm{t}+36]$ & $25.06^{* * *}(0.0001)$ & $25.27^{* * *}(0.0001)$ \\
\hline$\Delta$ Efficiency $[t+1, t+36]$ & $0.00(0.831)$ & $0.00(0.831)$ \\
\hline$\Delta$ Loan ratio $[t+1, t+36]$ & $1.31^{* *}(0.012)$ & $1.28 * *(0.015)$ \\
\hline$\Delta \operatorname{Risk}[\mathrm{t}+1, \mathrm{t}+36]$ & $0.15^{* * *}(0.004)$ & $0.15^{* * *}(0.004)$ \\
\hline$\Delta$ Capital ratio $[\mathrm{t}+1, \mathrm{t}+36]$ & $1.34 *(0.053)$ & $1.33 *(0.055)$ \\
\hline$\Delta$ Deposit ratio $[t+1, t+36]$ & $-0.066 * * *(0.0001)$ & $-0.067^{* * *}(0.0001)$ \\
\hline$\Delta$ Assets growth $[\mathrm{t}+1, \mathrm{t}+36]$ & $0.26(0.115)$ & $0.265(0.114)$ \\
\hline Downturn & & $-0.042(0.524)$ \\
\hline Intercept & $1.23 * * *(0.0001)$ & $1.24 * * *(0.0001)$ \\
\hline Observations & 355 & 355 \\
\hline Adj R-Squared & 0.2626 & 0.2613 \\
\hline
\end{tabular}

Notes: The dependent variable are the Rolling BHR every the 36-month between 1997 and 2007. We calculate the change in operating indicator in the rolling periods. P-value is reported in parentheses. *, **, and *** indicate statistical significance at $10 \%, 5 \%$, and $1 \%$ levels, respectively (Based on t-statistics). 


\subsection{Robustness}

After we prove that the changed operating indicator is more suitable than the averaged operating indicator, we also show another regression analysis. In Shih's study [4], they examined bank mergers as a solution to banking sector crises and found the effect of bank mergers on bankruptcy risk in the Asian Financial Crisis. In this crisis environment, banking institutions faced this collapse, then many local governments encouraged or even forced failing banking institutions to merge. For example, in the Philippines, central bank Governor Gabriel Singson stated "The central bank favors mergers as a way to keep the number of bank failures to a minimum... We would like to encourage mergers among our banks even before problems arise, to the extent that these will result in stronger banking institutions” (Dow Jones Newswires [25]).

Because the Asian Financial Crisis was happened in 1997, to avoid that our result may be interfered by this crisis. We separate our sample form the transaction which happened in 1997-2000 and in 2001-2007. We want to find if there is a significant effect on the transaction which is passive or active in the long-run performance. This result shows in Table 14. We also calculate the operating indicator by the change every rolling 36-month from 1997 to 2007. Model 11 reveals the regression result in 1997-2000, and model 12 reveals the regression result in 2001-2007. Comparing model 11 and model 12, we find that ROA still have a significant effect on the ling-run performance in both model 11 and model 12.In model 11, $\Delta$ capital ratio and $\Delta$ deposit ratio are noticed a significant effect on the long-run performance. It may because that the passive transaction which happened in 1997-2000 made that the acquirer have a high capital structure by the government's help. While $\Delta$ risk has a significant effect in model 11, model 12 shows an insignificant effect on the long-run performance. It means that the improvement of risk is not affected after the Asian Financial Crisis.

In Table 3, we find that the sample comes primarily from Japan (87 deals, 29.69\%) and notice that Japan must be evaluated separately because it has the most experiences with M\&A and it is the only country in our sample that can be considered developed. The previous study stated that Japan is the first country which was forced to merge by the government. In order to investigate the different country structures, we classify our sample by the targets' nation such as North Asia, Asia-Pacific, Japan and Southeast Asia. Model 12 and model 13 show the regression result of Japan and Southeast Asia in Table 15, respectively. And, we calculate the operating indicator by

\section{Table 14. Regression analysis of the sample classified by year.}

\begin{tabular}{ccc}
\hline Variables & Model 11 & Model 12 \\
\hline Frequency of merger & $0.15(0.311)$ & $-0.123^{*}(0.066)$ \\
Domestic merger & $-0.249(0.154)$ & $-0.104(0.229)$ \\
Transaction value & $-0.031(0.275)$ & $0.00(0.083)$ \\
Relative size & $-0.002(0.115)$ & $25.21^{* * *}(0.0001)$ \\
$\Delta$ ROA $[\mathrm{t}+1, \mathrm{t}+36]$ & $20.320^{* * *}(0.0001)$ & $0.00(0.782)$ \\
$\Delta$ Efficiency[t+1, $\mathrm{t}+36]$ & $0.00(0.898)$ & $1.062(0.125)$ \\
$\Delta$ Loan ratio[t $+1, \mathrm{t}+36]$ & $-0.184(0.792)$ & $0.007(0.96)$ \\
$\Delta$ Risk $[\mathrm{t}+1, \mathrm{t}+36]$ & $0.155^{* * *}(0.008)$ & $-1.062(0.408)$ \\
$\Delta$ Capital ratio $[\mathrm{t}+1, \mathrm{t}+36]$ & $2.103^{* *}(0.042)$ & $0.018(0.363)$ \\
$\Delta$ Deposit ratio[t $+1, \mathrm{t}+36]$ & $0.054^{* *}(0.045)$ & $-0.179(0.346)$ \\
$\Delta$ Assets growth $[\mathrm{t}+1, \mathrm{t}+36]$ & $0.156(0.538)$ & $0.081(0.436)$ \\
Intercept & $0.11(0.385)$ & 1950 \\
Observations & 0.0681 & 0.2032 \\
\hline
\end{tabular}

Notes: We separate our sample form the merger happened in 1997-2000 (Model 11) from happened in 2001-2007 (Model 12). The dependent variable are the Rolling BHAR relation to the performance of the MSCI AC ASIA index, every the 36-month between 1997 and 2007 . We calculate the change in operating indicator in the rolling periods. P-value is reported in parentheses. *, **, and *** indicate statistical significance at $10 \%$, $5 \%$, and $1 \%$ levels, respectively (Based on t-statistics). 
Table 15. Regression analysis of the sample classified by the targets' nations.

\begin{tabular}{|c|c|c|}
\hline Variables & Model 13 & Model 14 \\
\hline Frequency of merger & $0.081(0.516)$ & $0.013(0.924)$ \\
\hline Domestic merger & - & $0.154(0.239)$ \\
\hline Transaction value & $-0.042^{* * *}(0.003)$ & $0.03(0.301)$ \\
\hline Relative size & $0.076^{* * *}(0.002)$ & $0.00(0.235)$ \\
\hline$\Delta \mathrm{ROA}[\mathrm{t}+1, \mathrm{t}+36]$ & $8.001(0.375)$ & $19.262 * * *(0.004)$ \\
\hline$\Delta$ Efficiency $[t+1, t+36]$ & $0.00(0.22)$ & $-0.011 * *(0.012)$ \\
\hline$\Delta$ Loan ratio $[\mathrm{t}+1, \mathrm{t}+36]$ & $0.134(0.857)$ & $0.794(0.436)$ \\
\hline$\Delta \operatorname{Risk}[\mathrm{t}+1, \mathrm{t}+36]$ & $-0.256^{*}(0.069)$ & $0.154^{* *}(0.023)$ \\
\hline$\Delta$ Capital ratio $[\mathrm{t}+1, \mathrm{t}+36]$ & $3.862 *(0.089)$ & $1.847(0.628)$ \\
\hline$\Delta$ Deposit ratio[t $+1, t+36]$ & $0.052 * * *(0.004)$ & $0.02(0.755)$ \\
\hline$\Delta$ Assets growth $[\mathrm{t}+1, \mathrm{t}+36]$ & $-0.258(0.492)$ & $0.024(0.932)$ \\
\hline Intercept & $-0.25 *(0.075)$ & $-0.136(0.382)$ \\
\hline Observations & 171 & 85 \\
\hline Adj R-Squared & 0.2027 & 0.1495 \\
\hline
\end{tabular}

Notes: We classify our sample by the targets’ nation such as North Asia, Asia-Pacific, Japan and Southeast Asia. Because the result is not significant at all variables in North Asia and Asia-Pacific, we do not show their regression analysis in Table 15. The regression analysis of the sample in Japan is showing in model 13, and the sample in Southeast Asia is showing in model 14. And, all samples in Japan are domestic merger, so this variable is not available. The dependent variable are the Rolling BHAR relation to the performance of the MSCI AC ASIA index, every the 36-month between 1997 and 2007. We calculate the change in operating indicator in the rolling periods. P-value is reported in parentheses. *, **, and *** indicate statistical significance at $10 \%, 5 \%$, and $1 \%$ levels, respectively (Based on t-statistics).

the change every rolling 36-month from 1997 to 2007.

Because all samples in Japan are domestic merger, this variable is not available. We find that $\Delta \mathrm{ROA}$ is insignificant effect on the long-run performance in model 13, and cannot prove that Japan bank merger has profitability improvement after the merger. The improvement of efficiency also has insignificant effect on the long-run performance of Japan bank merger. Because that the Japanese has a high national consciousness, so we speculate that they may follow the rule of government announced to merge to help the bankruptcy bank. However, we prove that the long-run performance of Japan bank merger is not complete. Moreover due to the sample comes primarily from Japan, we suspect that it is maybe a reason for why the long-term performance in Asian bank merger cannot be similar with the US and the EU market. After comparing the two regression result between model 13 and model 14, we find a key point.

We mention before that the domestic bank merger which is passive and forcing transactions have a negative effect on the long-run performance, and the cross-border merger which is active transactions have a positive effect on the long-run performance. All samples in Japan are domestic merger (97.7\%), and we can say it is a reason for why the performance of Japan bank merger is not complete. On the other hand, the transaction of Southeast Asia is major from cross-border merger (51.4\%), and the cross-border acquirer has more aspiration to operating the combined bank to achieve a high performance. So, the performance of Southeast Asia is better that Japan.

\subsection{Effects of the Deal Attribute on the Operating Indicator}

Now, we further illustrate the effects of the deal attribute on the operating indicator in Table 16. And, we calculate the operating indicator by the average every rolling 36-month from 1997 to 2007. The results can be comparison with the Table 10. Domestic merger and transaction value have a significant effect on the operating indicator performance. When the merger has a high transaction values in cross-border merger, ROA and capital ratio have great improvement. At the same time, when the merger has a low transaction values in domestic merger, 
Table 16. Regression analysis of the operating indicator on the deal attribute.

\begin{tabular}{ccccc}
\hline Variables & ROA $[\mathrm{t}+1, \mathrm{t}+36]$ & Loan ratio $[\mathrm{t}+1, \mathrm{t}+36]$ & Capital ratio $[\mathrm{t}+1, \mathrm{t}+36]$ & Deposit ratio $[\mathrm{t}+1, \mathrm{t}+36]$ \\
\hline Frequency of merger & $-0.003^{* * *}(0.001)$ & $0.042^{* * *}(0.002)$ & $-0.007(0.273)$ & $3.171^{* * *}(0.0001)$ \\
Domestic merger & $-0.003^{* * *}(0.004)$ & $0.033^{* *}(0.018)$ & $-0.084^{* * *}(0.0001)$ & $5.113^{* * *}(0.0001)$ \\
Transaction Value & $0.00(0.247)$ & $-0.019^{* * *}(0.0001)$ & $0.004^{* * *}(0.0001)$ & $-0.862^{* * *}(0.0001)$ \\
Relative ratio & $0.00(0.115)$ & $0.00(0.718)$ & $0.00(0.551)$ & $-0.002^{* *}(0.021)$ \\
Downturn & $-0.002(0.114)$ & $-0.038^{* *}(0.039)$ & $0.02^{* *}(0.021)$ & $-0.174(0.769)$ \\
Dummy & $-0.001(0.6)$ & $0.089^{* * *}(0.0001)$ & $-0.02^{*}(0.077)$ & $-0.815(0.307)$ \\
Intercept & $0.008^{* * *}(0.0001)$ & $0.662^{* * *}(0.0001)$ & $0.157^{* * *}(0.0001)$ & $6.862^{* * *}(0.0001)$ \\
Observations & 355 & 355 & 355 & 355 \\
Adj R-Square & 0.127 & 0.263 & 0.53 & 0.649 \\
\hline
\end{tabular}

Notes: The dependent variable are the operating indicator over the 36-month between 1997 and 2007. The dummy variable is added to represent the transaction happened in 1997. P-value is reported in parentheses.*, **, and *** indicate statistical significance at $10 \%, 5 \%$, and $1 \%$ levels, respectively (Based on t-statistics).

loan ratio and deposit ratio have great improvement. The relative size is found to have no impact on the operating indicator, and is consistent with previous studies. Judging from the above, the effect of the deal attribute on the operating indicator is significant but the level of effect is decreased gradually as time goes on.

\section{Conclusions}

In this paper, we investigate the long-run performance of Asian acquiring bank by using 293 bank mergers after the merger in the 1997-2007 periods. To analyze the long-run performance, we verify the acquirers' long-run performance by the Buy-and-Hold Abnormal Returns (BHAR). BHAR is considered in the regression models by rolling every 36-month from 1997 to 2007 to eliminate the problem of cross-sectional dependence. Variables are separating the deal attribute from the acquirer bank's operating indicators. Then, we also add a dummy variable for the effect of the Asian Financial Crisis, which happened in 1997 to 1998 . We have the following conclusions:

First, we find significant negative long-run abnormal returns for Asian commercial banks and bank holding companies in the rolling period after post-merger and as well as the short-run performance. Our conclusion shows that the bank mergers cannot create the synergy in the long run. Second, consistent with the previous studies, our result also reveals that the deal attribute has significant negative related to the stock market returns.

Third, it shows that ROA has a significantly positive effect on the long-run performance, but unlike the previous studies, efficiency only shows a slightly significant improvement. The previous studies concluded that the early bank mergers can be efficiency improving, and stockholder value still remains inconclusive. In contrast, the recent bank mergers appear both efficiency and stockholder value enhanced. It could be because that the recent bank mergers learned best-practices (and worst-practices) from the early bank mergers (DeYoung, Evanoff and Molyneux [1]). We can say that Asian financial industry learned the experience of the US and the EU by observing, and generating knowledge that is exploitable in Asia financial mergers. However there are still dissimilarities with the previous studies due to the different geography and the level of development. Additionally, we speculate that because the Asia market is not very efficient, so the conclusion is not consistent with the US and the EU market.

Within the different calculations of the operating indicator in regression models, we find that the change in operating indicator is more suitable than the average in operating indicator for BHAR and BHR. Eventually, the effect of the Asian Financial Crisis is insignificant. This means that even the Asian financial Crisis brings the amount of mergers, it could not result in the value for the acquirer after the mergers. Therefore, our empirical results show that the long-run stock returns and operating performance of Asian commercial bank mergers are different from those of the US and EU markets.

\section{References}

[1] DeYoung, R., Evanoff, D.D. and Molyneux, P. (2009) Mergers and Acquisitions of Financial Institutions: A Review of 
the Post-2000 Literature. Journal of Financial Services Research, 36, 87-110.

http://dx.doi.org/10.1007/s10693-009-0066-7

[2] Group of Ten (2001) Report on Consolidation in the Financial Sector. Bank for International Settlements, Basel.

[3] Altunbas, Y. and Marqués, D. (2008) Mergers and Acquisitions and Bank Performance in Europe: The Role of Strategic Similarities. Journal of Economics \& Business, 60, 204-222.

http://dx.doi.org/10.1016/j.jeconbus.2007.02.003

[4] Shih, M.S.H. (2003) An Investigation into the Use of Mergers as a Solution for the Asian Banking Sector Crisis. The Quarterly Review of Economics and Finance, 43, 31-49. http://dx.doi.org/10.1016/S1062-9769(01)00135-1

[5] Cybo-Ottone, A. and Murgia, M. (2000) Mergers and Shareholder Wealth in European Banking. Journal of Banking and Finance, 24, 831-859. http://dx.doi.org/10.1016/S0378-4266(99)00109-0

[6] Hagendorff, J., Collins, M. and Keasey, K. (2008) Investor Protection and the Value Effects of Bank Merger Announcements in Europe and the US. Journal of Banking and Finance, 32, 1333-1348. http://dx.doi.org/10.1016/j.jbankfin.2007.11.008

[7] Diaz, B.D., Olalla, M.G. and Azofra, S.S. (2004) Bank Acquisitions and Performance: Evidence from a Panel of European Credit Entities. Journal of Economics and Business, 56, 377-404. http://dx.doi.org/10.1016/j.jeconbus.2004.02.001

[8] DeLong, G.L. and DeYoung, R. (2007) Learning by Observing: Information Spillovers in the Execution and Valuation of Commercial Bank M\&As. Journal of Finance, 62, 181-216. http://dx.doi.org/10.1111/j.1540-6261.2007.01205.x

[9] Resti, A. and Siciliano, G. (2001) Do Bank Acquisitions Increase Shareholders’ Wealth? A Comparison between Market-Based and Accounting-Based Performance Indicators for Some Italian Banks. Working Paper, Social Science Research Network.

[10] Houston, J.F., James, C.M. and Ryngaert, M.D. (2001) Where Do Merger Gains Come from? Bank Mergers from the Perspective of Insiders and Outsiders. Journal of Financial Economics, 60, 285-331. http://dx.doi.org/10.1016/S0304-405X(01)00046-0

[11] Knapp, M., Gart, A. and Chaudhry, M. (2006) The Impact of Mean Reversion of Bank Profitability in Post-Merger Performance in the Banking Industry. Journal of Banking and Financial, 30, 3502-3517.

[12] Hagendorff, J. and Keasey, K. (2009) Post-Merger Strategy and Performance: Evidence from the US and European Banking Industries. Account Finance, 4, 725-751. http://dx.doi.org/10.1111/j.1467-629X.2009.00306.X

[13] Koetter, M. (2005) Evaluating the German Bank Merger Wave. Tjalling C. Koopmanns Discussion Paper No. 05-16, Tjalling C. Koopmans Research Institute.

[14] Behr, A. and Heid, F. (2008) The Success of Bank Mergers Revisited—An Assessment Based on a Matching Strategy. Deutsche Bundesbank Discussion Paper Series 2: Banking and Financial Studies, No. 06/2008.

[15] Campa, J.M. and Hernando, I. (2006) M\&As Performance in the European Financial Industry. Journal of Banking and Financial, 30, 3367-3392. http://dx.doi.org/10.1016/j.jbankfin.2006.06.006

[16] Scholtens, B. and De Wit, R. (2004) Announcement Effects of Bank Mergers in Europe and the US. Research in International Business and Finance, 18, 217-228. http://dx.doi.org/10.1016/j.ribaf.2004.04.002

[17] Berger, A.N. and DeYoung, R. (2002) Technological Progress and the Geographic Expansion of the Banking Industry. FRB Chicago Working Paper No. 2002-07, Federal Reserve Bank of Chicago, Chicago, 494-508.

[18] Liu, W., Kolari, J.W., Tippens, T.K. and Fraser, D.R. (2011) Did Capital Infusions Enhance Bank Recovery from the Great Recession? Working Paper.

[19] Dutta, S. and Jog, V. (2009) The Long-Term Performance of Acquiring Firms: A Re-Examination of an Anomaly. Journal of Banking \& Finance, 33, 1400-1412. http://dx.doi.org/10.1016/j.jbankfin.2009.02.004

[20] Barber, B.M. and Lyon, J.D. (1997) Detecting Long-Run Abnormal Stock Returns: The Empirical Power and Specification of Test Statistics. Journal of Financial Economics, 43, 341-372. http://dx.doi.org/10.1016/S0304-405X(96)00890-2

[21] Gregory, A. (1997) An Examination of the Long-Run Performance of UK Acquiring Firms. Journal of Business Finance and Accounting, 24, 971-1002.

[22] Cornett, M.M., Fayman, A., Marcus, A.J. and Tehranian, H. (2011) Dividends, Maturity, and Acquisitions: Evidence from a Sample of Bank IPOs. Review of Financial Economics, 20, 11-21. http://dx.doi.org/10.1016/j.rfe.2010.11.001

[23] Cheng, D.C., Gup, B.E. and Wall, L.D. (1989) Financial Determinants of Bank Takeovers. Journal of Money, Credit and Banking, 21, 524-536. http://dx.doi.org/10.2307/1992359

[24] DeYoung, R. (1997) X-Efficiency and Management Quality in National Banks. Journal of Financial Services Research, 15.

[25] Dow Jones Newswires (1998) Philippines to Attempt to Spur Bank Mergers. The Asian Wall Street Journal, 22. 